\title{
Influence of Grain Shape of Waste Glass Aggregate on the Properties of Cement Mortar
}

\author{
Katarzyna Skoczylas', Teresa Rucińska ${ }^{1 *}$ \\ 1 Department of Building Physics and Building Materials, Faculty of Civil Engineering and Architecture, West \\ Pomeranian University of Technology, Szczecin, al. Piastów 50, 70-311 Szczecin, Poland \\ * Corresponding author's e-mail:Teresa.Rucinska@zut.edu.pl
}

\begin{abstract}
The rapid civilizational progress forces us care more about the natural environment. A huge population produces immeasurable amounts of waste, including vast amounts of waste glass. Therefore, the recycling of waste glass is a challenge that has to be taken on to preserve the balance in our environment. The development of the nanomaterial technology, allowed us to obtain the cement mortars with similar or even enhanced parameters compared to the ordinary ones. These two aspects have become an inspiration for the research, in which waste glass was used along with modern nanomaterial technology. Three groups of mortars, where the natural aggregate was replaced by waste glass $(100 \%-\mathrm{WG}, 50 \%-\mathrm{RWG}, 0 \%-\mathrm{R})$ were prepared. Each group of mortars was modified with nanosilica admixture of $0 \%, 1 \%$ and $3 \%$ (of cement mass). Superplasticizer was incorporated in order to improve the workability of mortars. The workability and density of fresh mortar were determined. The specimens were cured for 7, 28 and 365 days, after which their freeze-thaw resistance and abrasion resistance were evaluated. The study showed that the waste glass aggregate might find application in the construction industry as the mortars produced with the waste glass and nanosilica exhibited improved mechanical properties. The analysis of the results of this experimental research allowed for determining the influence of grain shape of waste glass aggregate on the properties of cement mortar.
\end{abstract}

Keywords: cement mortar, waste glass aggregate, nanosilica

\section{INTRODUCTION}

Rapid development of our civilization had a negative effect on our environment. An idea of sustainable development was proposed to help the new generations. The initial definition appeared in 1987 and stated that "Humanity has the ability to make development sustainable to ensure that it meets the needs of the present without compromising the ability of future generations to meet their own needs" [Report, 1987]. The idea was further developed in the Action Programme - Agenda 21 in 1992 [United Nations, 1992]. The objective of the sustainable development is to create a strong correlation between ecology, economy and society. In particular, the degradation of the environment should be limited, while maintaining the economic growth and decent standard of living.
One of the key elements in the sustainable development idea is an efficient use of resources. The modern technology allows us to enhance the properties of the materials on a micro- or a nanoscale. However, some materials are not replaceable and non-renewable. The sustainable development idea backed by the strict regulation of the EU mandate the recycling of waste. According to the newest European Union Directives [Directive (EU) 2018/852], at least 55\% of produced municipal waste in the European Union should be recycled till 2025. The numbers will be increased to $60 \%$ in 2030 and $65 \%$ in 2035 . The recycling goal for the processed food packages was set to $65 \%$ in 2025 and $70 \%$ in 2030 . The numbers for glass packaging were set to $70 \%$ in 2025 and $75 \%$ in 2030. In 2035 , less than $10 \%$ of packaging should be sent to landfills. The rest is intended for the ecological waste incineration plants. 
According to the Central Statistical Office in Poland [GUS, 2018] $126 \mathrm{Mt}$ of waste was produced domestically, showing a $10 \%$ decrease over the previous year. In total, $49 \%$ was recycled, $42 \%$ was disposed by landfilling and $4 \%$ was disposed in another way. The general production of municipal waste in Poland was lower compared to other European countries. A statistical Pole produced $311 \mathrm{~kg}$ of waste in 2017, with the European average at $483 \mathrm{~kg}$. The highest numbers were exhibited in Denmark - $777 \mathrm{~kg}$ of waste produced per capita. The general numbers show that $29 \%$ of waste is recycled, $27 \%$ is disposed of by incineration, $26 \%$ is landfilled and $16 \%$ is composted. The numbers for packaging are promising. In $2017,62.0 \%$ and $57.7 \%$ were recovered or recycled, respectively.

Glass is one of the most common materials used in packaging. There are several benefits in terms of ecology, economy and technology from recycling of glass. Every Mt of the recyclate allows to spare approx. $800 \mathrm{~kg}$ of sand, $250 \mathrm{~kg}$ of soda ash, $180 \mathrm{~kg}$ of lime stone powder, $250 \mathrm{~kg}$ of lime stone and $270 \mathrm{~kg}$ of table salt [Kuśnierz, 2010]. According to Williams [Wiliams, 1998] increasing the amount of waste glass up to $50 \%$ in the blast furnace mix decreases the energy usage by $35 \%$. A $1 \%$ cullet addition decreases the production process energy demand by $8 \mathrm{~kJ} / \mathrm{kg}$ [ISIC,1992]. Glass cullet also extends the lifespan of the blast furnace [Pawłowski and Stoch, 1995]. The work normally used for acquiring initial resources can be spent elsewhere. Using cullet for the production of glass also reduces the
$\mathrm{CO}_{2}, \mathrm{SO}_{2}, \mathrm{Cl}, \mathrm{F}$, dust and $\mathrm{NO}_{\mathrm{X}}$ emission and water consumption up to $50 \%$ [Journal of the WRF, 1996]. Glass cullet is usually free of contaminants and can be re-used in glass furnaces without any additional cleaning processes [Sordon-Kulibaba, 2008]. Cullet can also be used for the production of glass fibres and mats, insulation plates, foam glass, glass balls, plaster grit and as an additive in ceramic masses, cleaning pastes or cement mortars.

The aim of the study was to evaluate the influence of the shape of recycled glass aggregate on the properties of cement mortars. The cement mortars were modified by replacing $50 \%$ or $100 \%$ of natural sand by waste glass aggregate. The aim of the study was proposed based on the previously published research [Horszczaruk et al., 2014, Sikora et al., 2016, Skoczylas and Rucińska, 2018].

\section{METHODOLOGY}

\section{Natural sand and glass cullet}

The glass cullet grains have a smooth surface, are elongated and have clearly visible edges (Fig. 1). Natural sand grains (Fig. 2) are round and have harsh surface.

Elemental composition of both aggregates show similarities (Fig. 3, Fig. 4).

The data presented in the Table 1 [Ismail and Al-Hashmi, 2009] show that both natural sand and glass cullet have similar physical properties.

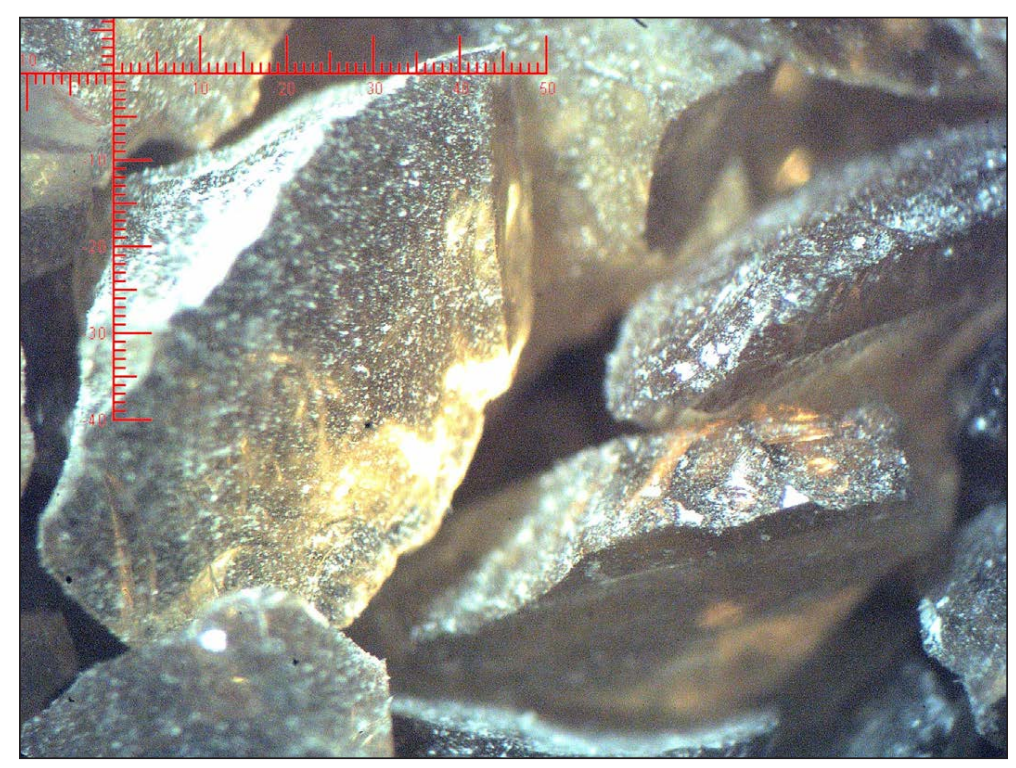

Figure 1. Glass cullet grains $1.6 / 2.0 \mathrm{~mm}$; 25x magnification 


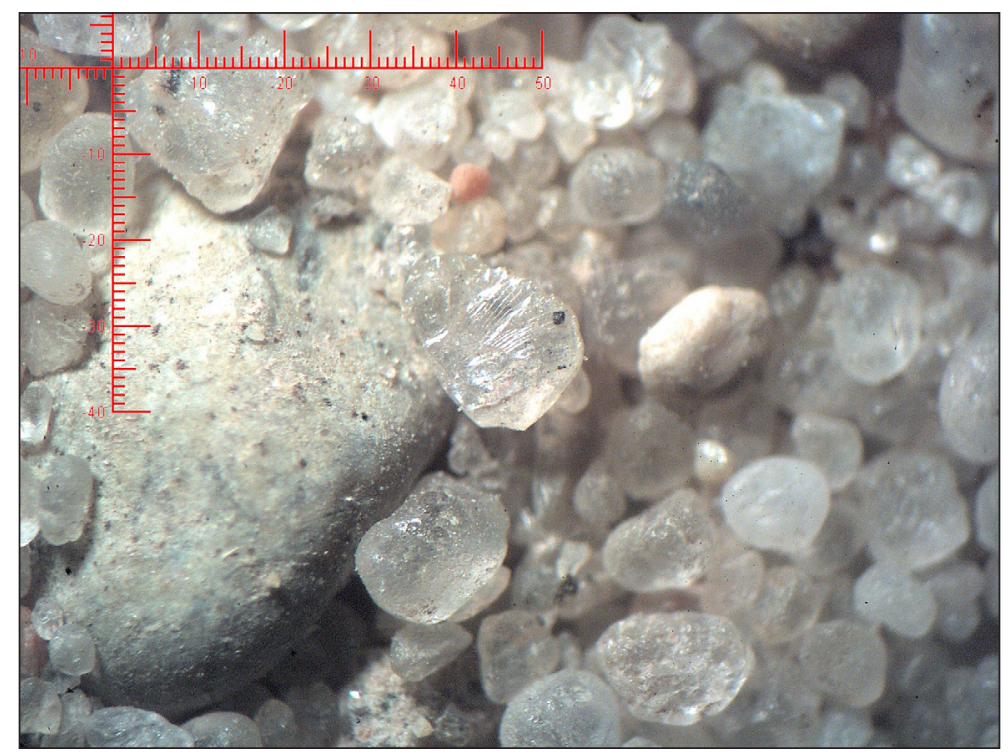

Figure 2. Natural sand, 25x magnification

a)

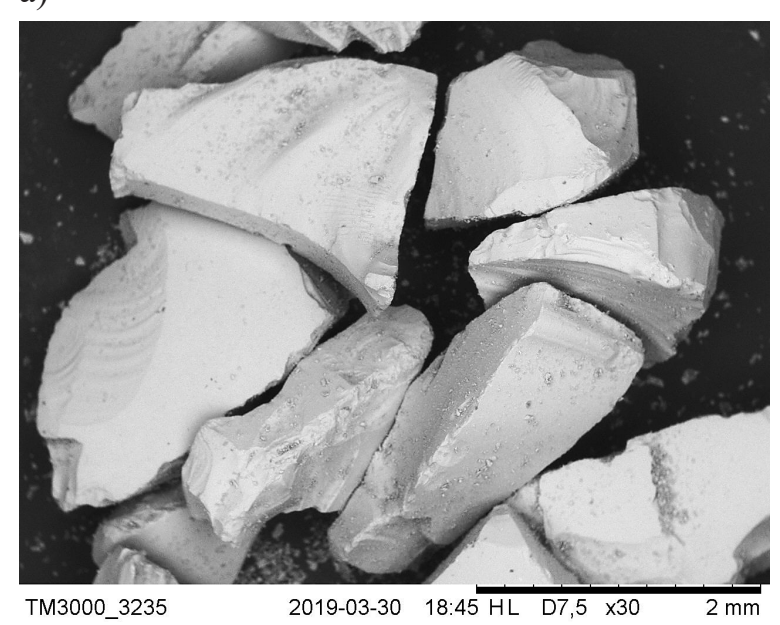

b)

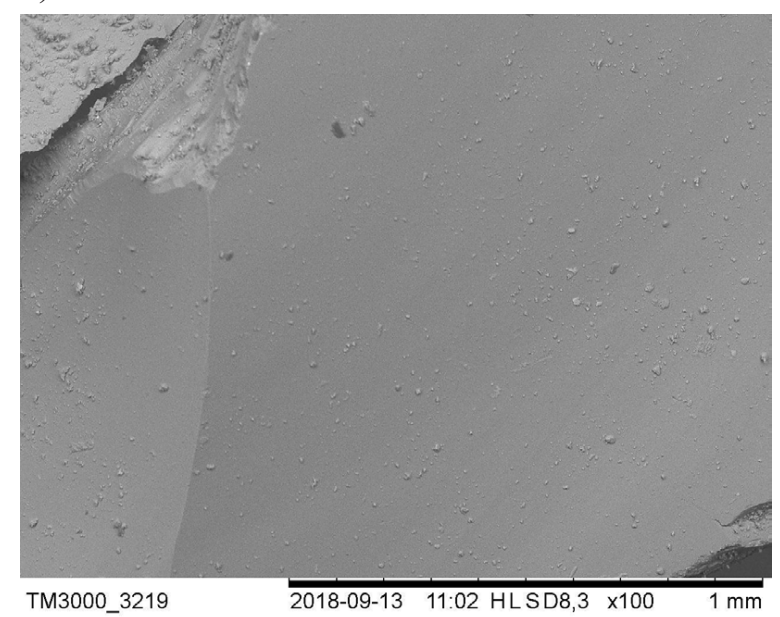

c)

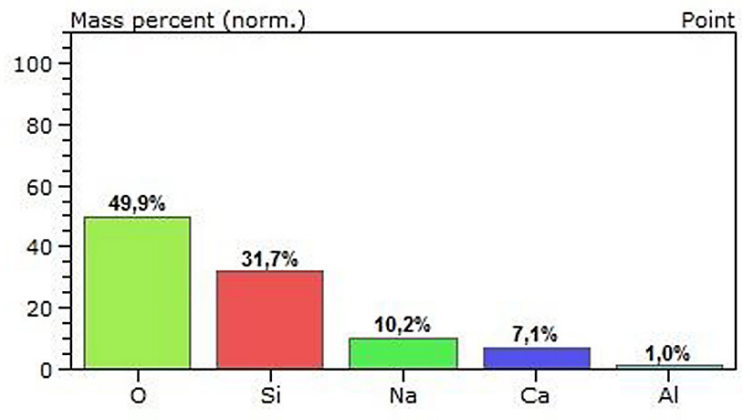

Figure 3. (a) Milled cullet grains; b) Rough shape with visibly smooth surface; c) elemental composition

Glass cullet exhibits lower absorption than natural sand, which was proven in other studies [Pereira de Oliveira et al, 2008, Skoczylas and Rucińska, 2018]. The study conducted by Terro [Terro, 2006] determined that due to smooth and impenetrable surface and lower absorption glass cullet increases the workability of the mix. A typical pozzolan material has a high silicate content and high specific surface area. Glass cullet has a high silicate content and an amorphous structure [Gopalakrishnan and Govindarajan, 2011]. The research [Carsana, 2014] showed that the addition 
a)

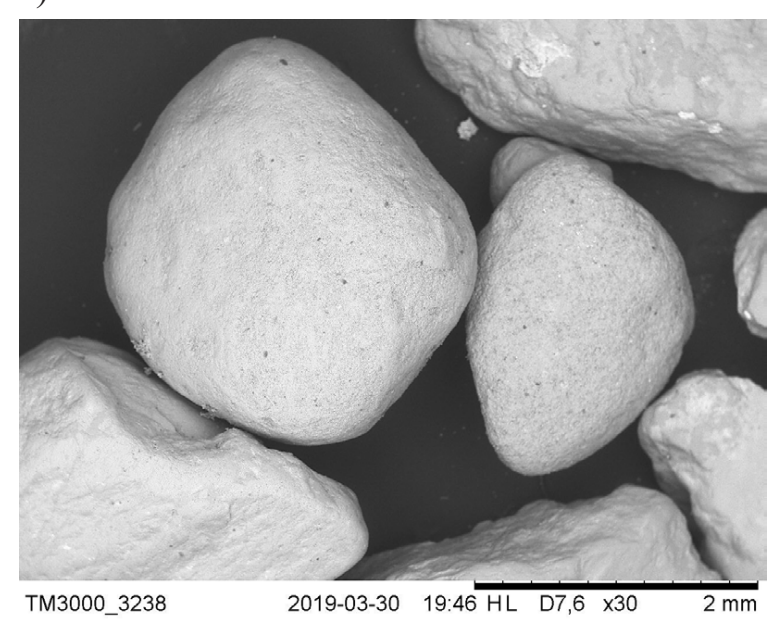

b)

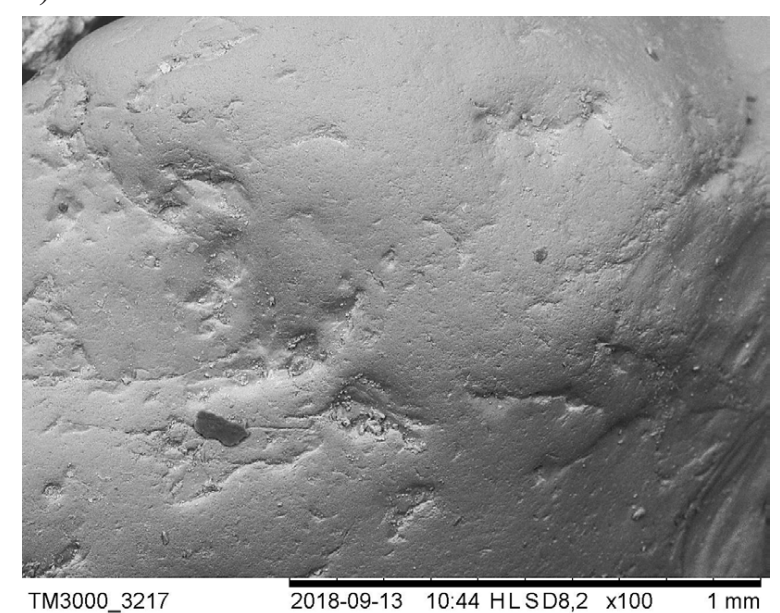

c)

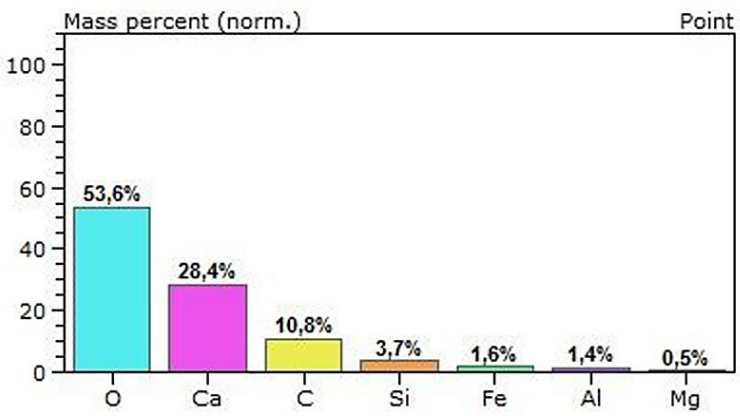

Figure 4. a) Natural sand grains; b) shape of single grain; c) elemental composition

of the milled glass cullet to cement mortars increased the pozzolanic activity. The addition of glass cullet increases the thermal properties of mortars reduces the absorption of cement mortars.

The research conducted by Du and Tan [Du and Tan, 2014] showed that the addition of waste glass caused a small decrease in fresh mortar density, small increase in the air content and an insignificant change in slump flow. The addition of glass cullet increased the strength properties of mortars. The study has also determined that the waste glass can replace the natural sand in $100 \%$ without a significant change in the alkali-silica reaction (ASR). The effect of the ASR is often limited by the addition of mineral additives and chemical admixtures such as blast furnace slag

Table 1. Properties of sand and waste glass [Ismail and Al-Hashmi, 2009]

\begin{tabular}{|l|c|c|}
\hline Physical property & Sand & Waste glass \\
\hline Surface & Porous & Smooth \\
\hline Structure & Circural & Oblong and pointed \\
\hline Specific gravity $\left(\mathrm{g} / \mathrm{cm}^{3}\right)$ & 2.57 & 2.19 \\
\hline Absorption $(\%)$ & 2.71 & 0.39 \\
\hline
\end{tabular}

and silica fly ash. Milled waste glass can also be used to reduce this effect [Aly et al., 2012]. Several studies showed that the addition of glass cullet increased the strength of the mortars [Aly et al., 2012, Batayneh, 2007, Ismail and Al-Hashmi, 2009]. The study performed by Topcu and Canbaz did not concur those findings. The researchers determined that the compressive strength of mortars decreased with the increase of the waste glass content.

\section{Materials}

Two types of aggregates were used in this study. The waste glass aggregate was acquired domestically from a local recycling company. Brown bottles were shattered, cleaned from contaminants, milled and sifted into 5 different fractions (Fig. 5). Grading curve fits the requirements for standard CEN sand. The second aggregate comprised the natural sand. The mortars were prepared using ordinary CEM I 42.5 R Portland cement and tap water. Workability of the mortars was modified by using a BASF ACE 430 polycarboxylic polyether superplasticizer (PCE) and 


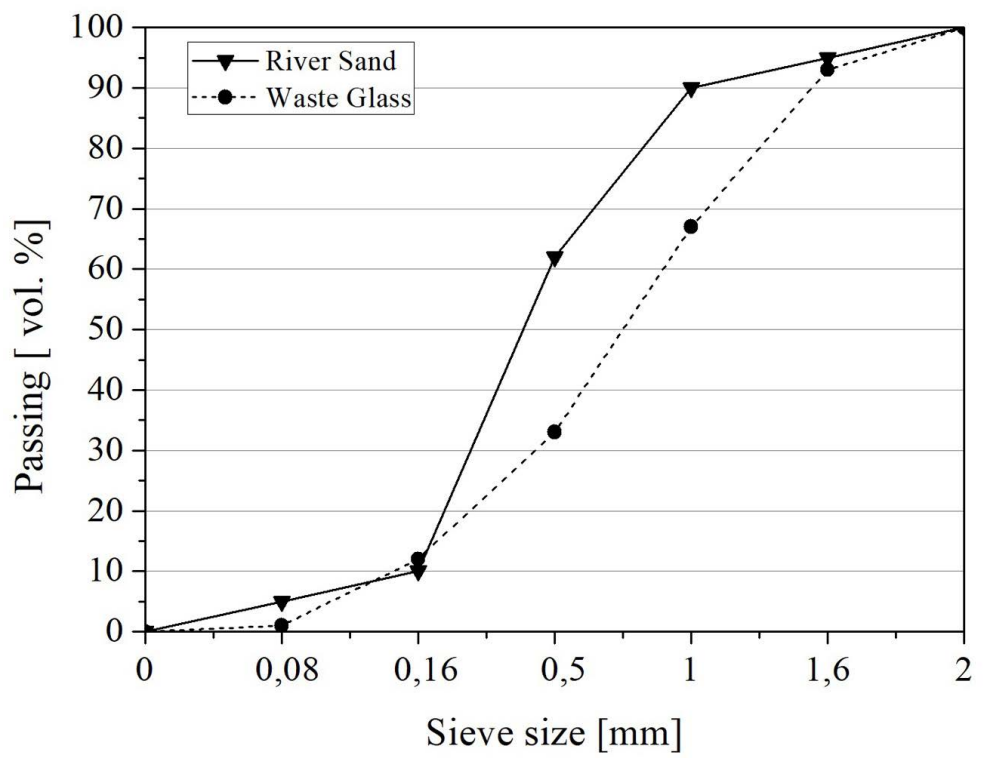

Figure 5. Waste glass aggregate after sifting into fractions

MasterRheobuild 1021 nanosilica suspension ( $20 \%$ of total solids). The water content of the suspension was incorporated in the total water content of the mix.

\section{Mix design}

The cement mortars were prepared in accordance with PN-EN 196-1. Three different sets of mortars with a constant cement-water-aggregate ratio (1:0.5:3) were prepared. The mortars were modified by replacing the natural sand by $50 \%$ or $100 \%$ of waste glass by volume. The designations are as follows: WG - mortars with $100 \%$ content of waste glass aggregate, RWG - mortars with mixed aggregate $50 \% / 50 \%, \mathrm{R}$ - mortars with $100 \%$ content of natural sand. Each set of mortars was than modified with the addition of nanosilica. The acquired mix proportions are presented in Table 2.

The samples were prepared using a standard automatic mortar mixer conforming to the PN-EN 196-1 standard. The filled molds were stored for 24 hours over a water surface at $\mathrm{T}=20^{\circ} \mathrm{C}$ and $\mathrm{RH} \geq 95 \%$. The samples were cured under the same conditions for 365 days.

\section{Test methods}

A fresh mix was tested according to PN-EN 1015-3 with the slump table. The bulk density of the fresh mix was determined in accordance with PNEN 1015-6 using the vibration method. The flexural strength and compressive strength of the hardened mortars were determined in accordance with PN-EN 1015-11 after 7, 28 and 365 days. The freeze/thaw resistance was tested in accordance with the domestic PN-B-04500:1985 standard on 40 x 40 × $160 \mathrm{~mm}$ samples. The specimens were subjected to 100 freeze/thaw $(4 \mathrm{~h} / 4 \mathrm{~h})$ cycles. The samples were afterwards oven dried and tested for strength. The results were compared to the reference specimen stored in a climatic chamber. The abrasion resistance of the samples was determined on a Bohme apparatus in accordance with PN-EN 1338:2003 using a $71 \pm 1.5 \mathrm{~mm}$ cube specimen.

Table 2. Mixture proportions of mortars

\begin{tabular}{|c|c|c|c|c|c|c|c|c|c|c|}
\hline \multirow{2}{*}{\multicolumn{2}{|c|}{ Components content }} & \multicolumn{9}{|c|}{ Sample designation } \\
\hline & & WG0 & WG1 & WG3 & RWG0 & RWG1 & RWG3 & Ro & R1 & R3 \\
\hline Waste glass content & \multirow{2}{*}{ (\%) } & 100 & 100 & 100 & 50 & 50 & 50 & - & - & - \\
\hline River sand content & & - & - & - & 50 & 50 & 50 & 100 & 100 & 100 \\
\hline Cement & \multirow{4}{*}{$\left(\mathrm{kg} / \mathrm{m}^{3}\right)$} & 519 & 519 & 519 & 519 & 519 & 519 & 519 & 519 & 519 \\
\hline Water & & 257 & 239 & 197 & 257 & 239 & 197 & 257 & 239 & 197 \\
\hline Nanosilica & & - & 26 & 78 & - & 26 & 78 & - & 26 & 78 \\
\hline Superplasticizer & & 3.6 & 3.6 & 3.6 & 1.6 & 1.6 & 1.6 & 1.6 & 1.6 & 1.6 \\
\hline
\end{tabular}




\section{RESULTS AND DISCUSSION}

\section{Consistency}

Figure 6 presents the results of the fresh mix slump test. All mortars exhibited plastic consistency. The highest slump flow was determined for the mixes without the nanosilica content (WG0, RWG0, R0). The amount of superplasticizer was established to obtain a comparable slump flow. For the mortars with $100 \%$ waste glass, the amount of the superplasticizer was set to $3.6 \mathrm{~kg} / \mathrm{m}^{3}$. For other groups the amount was set to $1.6 \mathrm{~kg} / \mathrm{m}^{3}$. There is a clearly visible influence of waste glass on the required amount of superplasticizer in the mix. Due to the sharp edges, waste glass aggregate causes blocking and reduces the workability of the mix [Polat et al., 2013]. The results are concurred by [Gunalan and Kanapathy Pillary, 2013]. With the increased content of the waste glass, the flowability of the mix decreased. [Park et al., 2004] stated that the accumulation of cement on the surface of cullet is responsible for the increase in friction. With the increase of the $\mathrm{nSiO}_{2}$ the mixes began to be more compacted. The effect occurs due to high water demand of the nanosilica.

\section{Loose and compacted bulk density of cement mortars}

Table 3 presents the results of loose and compacted bulk density determination. The results showed that the bulk density is proportional to the slump flow (Fig. 6). The highest bulk density was determined for the R0 mix. The lowest bulk density was observed for the WG0 mortar with waste glass aggregate. The bulk density was affected by the differences in grain shape and aggregate density: $2.19 \mathrm{~g} / \mathrm{cm}^{3}$ for waste glass and $2.57 \mathrm{~g} / \mathrm{cm}^{3}$ for natural sand [Ismail and Al-Hashmi, 2009]. The results show that the mixes without $\mathrm{nSiO}_{2}$ have a higher bulk density.

\section{Flexural and compressive strengths after 7 , 28 and 365 days of curing}

Figure 7 and 8 present the comparison of the flexural strength and compressive strength of mortars after 7 and 365 days to the values of both strength at 28 days (100\%) [Skoczylas and Rucińska, 2018].

The highest increase of flexural strength was observed during the first 7 days of curing. The samples reached at least $76 \%$ of their strength at 28 days and $62 \%$ of strength at 365 days. The effect of using the CEM I 42,5R with increased early strength was clearly visible. At the early age there were no significant differences between the strength of mortars. The differences in the obtained strength were visible after 28 days. The highest strength was obtained for mortar with WG0 waste aggregate. The mortar exhibited $13.8 \%$ higher strength than the initial R0 mortar. At 365 days, the difference reached $21 \%$. The mortars with mixed aggregate (RWG0) exhibited lower flexural strength at 28 days compared to reference mortar.

Table 3. The bulk density of fresh mix in loose and compacted state.

\begin{tabular}{|l|c|c|c|c|c|c|c|c|c|c|}
\hline \multicolumn{2}{|l|}{ Sample designation } & WG0 & WG1 & WG3 & RWG0 & RWG1 & RWG3 & R0 & R1 & R3 \\
\hline \multirow{2}{*}{ loose state } & \multirow{2}{*}[\mathrm{kg}/\mathrm{m}^{3}]{} & 2090 & 2080 & 2050 & 2100 & 2080 & 2060 & 2110 & 2080 & 2060 \\
\cline { 3 - 32 } & & 2130 & 2110 & 2090 & 2140 & 2120 & 2100 & 2140 & 2120 & 2100 \\
\hline
\end{tabular}

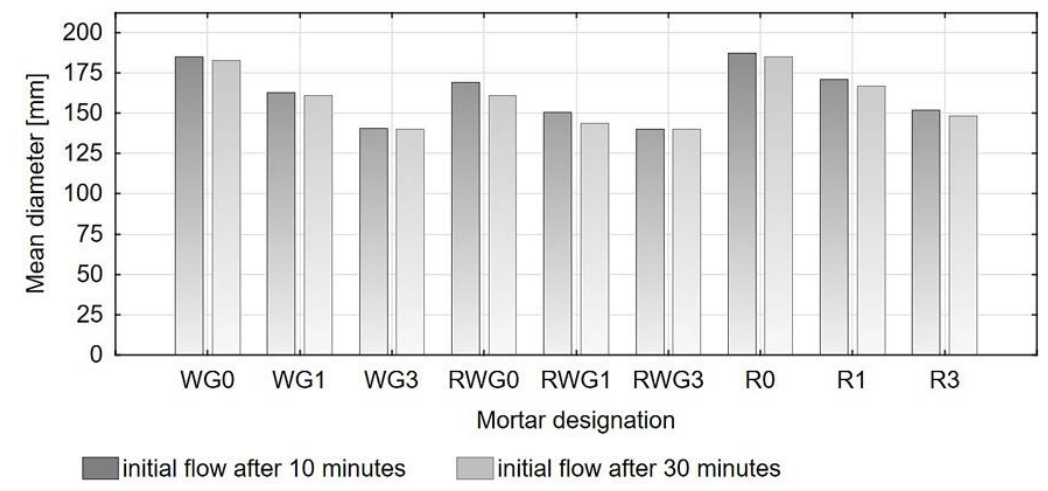

Figure 6. The consistency of fresh cement mortar 


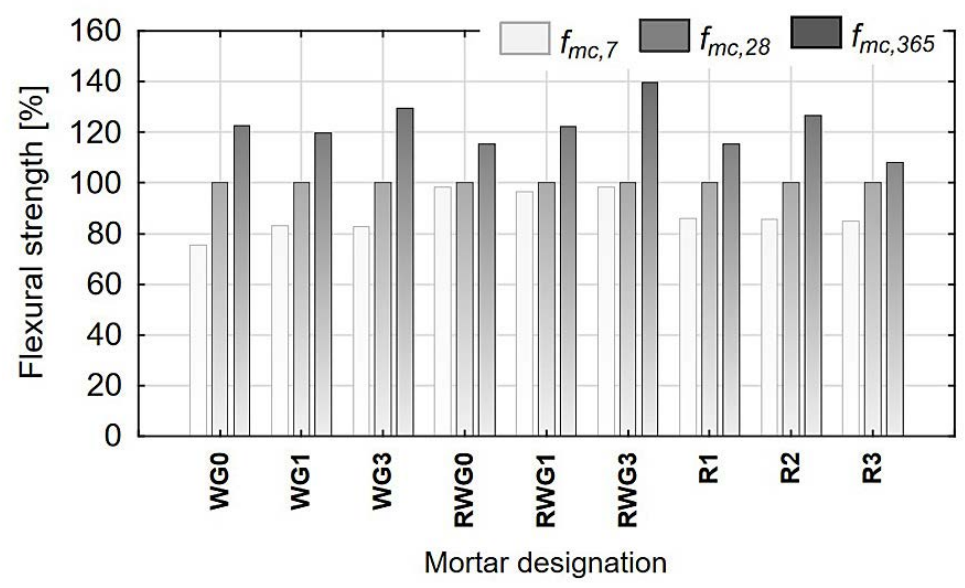

Figure 7. Flexural strength after 7, 28 and 365 days

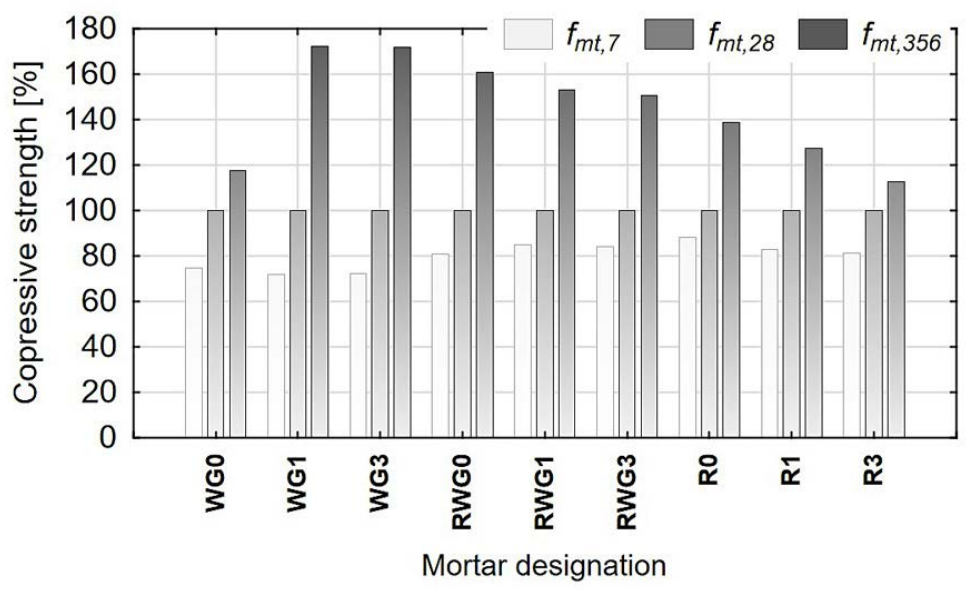

Figure 8. Compressive strength after 7, 28 and 365 days

The compressive strength results show that the mortars in the early stage of hardening acquired at least $72 \%$ of their total strength at 28 days and $42 \%$ of their strength after a year. The addition of the glass waste increases the compressive strength of mortars already at the early stages of curing. Several studies proved that replacing the natural sand with waste glass increases the strength parameters of cement mortars [Batayneh, 2007, Ismail and Al-Hashmi, 2009, Mageswari and Vidivelli, 2010]. The compressive strength of mortars with waste glass is increased due to the grain size due to enhancement of pozzolanic properties [Idir et al., 2010]. The enhancement of the compressive strength from the content of waste aggregate was obtained due to mechanical blocking, internal friction and increases specific surface area [Du and Tan, 2014].

The influence of nanosilica was the most significant in the case of the mortars with the addition of waste glass aggregate (WG). The addition of $1 \%$ and $3 \%$ of nanosilica enhanced both the flexural and compressive strength at every stage of curing. This proved the high activity of the nanosilica in the pozzolanic reaction. The reaction produces the C-S-H gel which fills in and strengthens the structure [Sikora et al., 2018]. Similar results were acquired by [Sikora et al., 2016]. In the case of the mortars with mixed aggregate (RWG3), the only visible increase in strength was visible at 365 days in the flexural strength test. The compressive strength of those mortars both at 28 days and 365 of curing was almost unchanged compared to reference mortar, regardless of the amount of added nanosilica. The addition of the nanosilica in the mortars with natural aggregate decreased the flexural strength at 28 days of curing. There were no significant differences in compressive strength. Concurring results were presented by [Beigi et al. 2013, Givi et al., 2011, Ltifi et al., 2011, 
Senff et al. 2012, Shakhmenko et al.,2013]. The effect might be caused by improper dispersion of nanosilica particles. In some cases, extensive amounts of nanosilica can cause clamping, decreasing locally the strength of cement matrix [Behfarnia and Salemi, 2013].

Figures 9-11 present the surfaces fractured after the flexural strength test. Figure 9 includes the WG3 samples. The fracture along the waste glass grain is sharp-edged and smooth. The fracture progressed both across the cement matrix and glass aggregate. Figure 10 shows a sample with mixed aggregate. The fractured glass aggregate had similar shape and smoothness as in a previous case. The shape of a fractured natural sand grains exhibited more irregularities. The fracture propagated through both aggregates. Figure 11 presents the fracture of sample with natural sand. The surface of the sample is highly irregular. The destruction of the sample progressed through the cement matrix.

\section{Freeze/thaw test}

Figures 12 and 13 present the samples after 25 and 100 cycles in a freeze/thaw chamber. A visual inspection of the samples showed clearly visible cracks on the surface of mortars with glass waste aggregate. The R0 mortar was completely destroyed (Fig. 13).

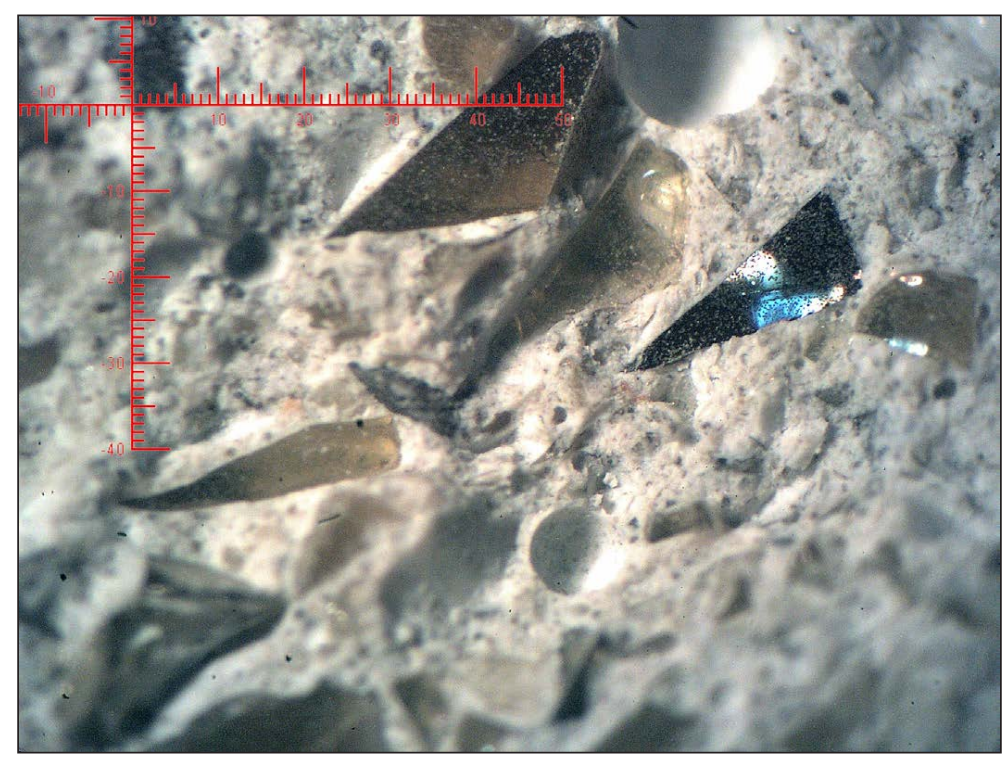

Figure 9. WG3 mortar, 25x magnification

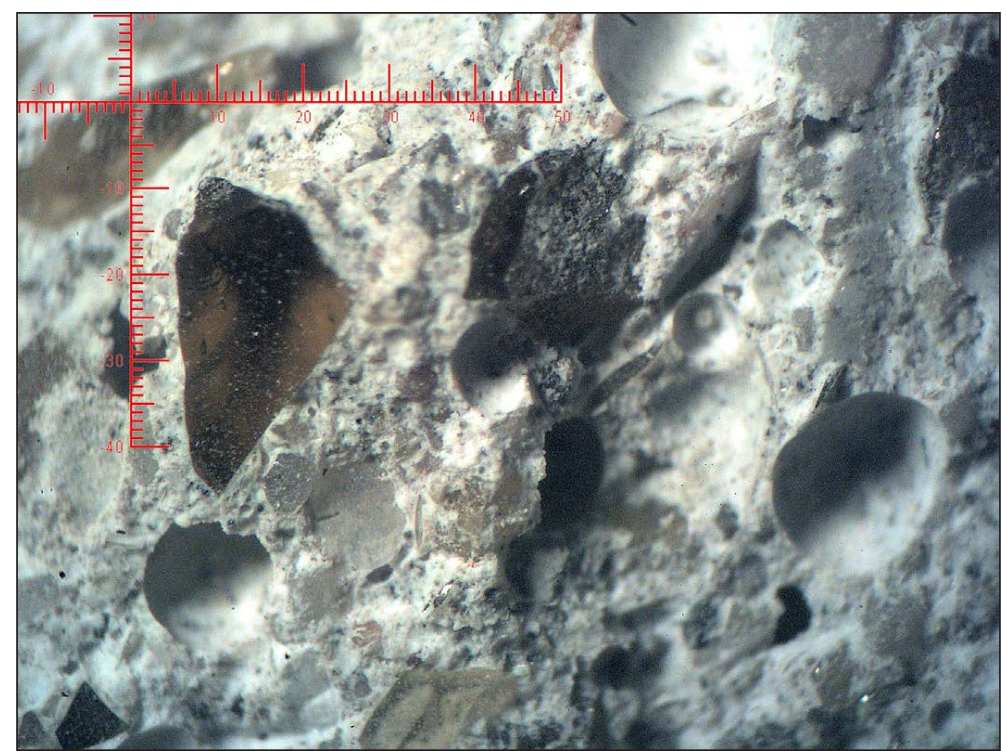

Figure 10. RWG3 mortar, 25x magnification 


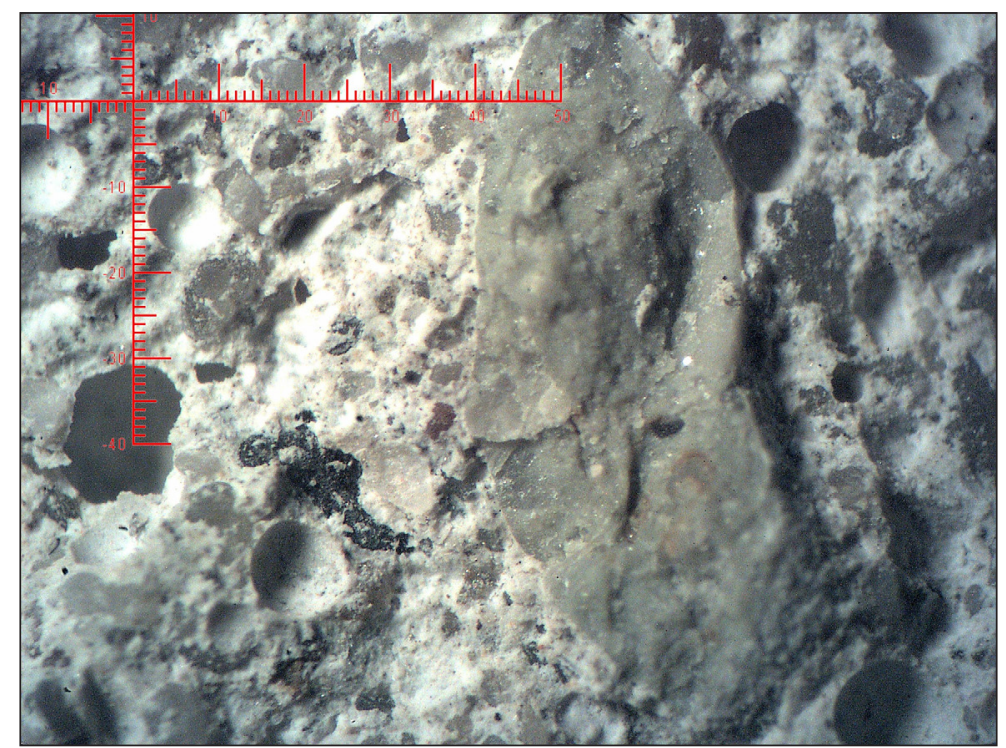

Figure 11. R3 mortar, 25x magnification

Figure 14 presents the changes in compressive strength of mortars after 100 freeze/thaw cycles. The smallest decrease in compressive strength was observed in the case of the WG3 mortar. The mortars with the waste aggregate exhibited a higher freeze/thaw resistance. The compressive strength decreases by approx. 7\%. Mixed aggregate mortars exhibited almost twice the drop in compressive strength. Natural sand mortars had five times lower compressive strength, thus exhibited the lowest freeze/thaw resistance. The R0 mortar was destroyed completely and was not included in the figure 14. The influence of nanosilica was clearly visible. The results are concurring with other study [Behfarnia and Salemi, 2013].
The aforementioned study showed that the mortars without the nanosilica after 300 freeze/thaw cycles were rejected for the compressive strength testing due to extensive damages to the specimen. The addition of $3 \%$ of nanosilica enabled to overcome the issue.

\section{Abrasion resistance}

The results of the abrasion test are presented in Table 4. The mortars without and with $1 \%$ of nanosilica exhibited a lower abrasion resistance. The 3\% addition of the nanosilica increased the abrasion resistance. The influence of the aggregate type on the abrasion resistance is similar, as

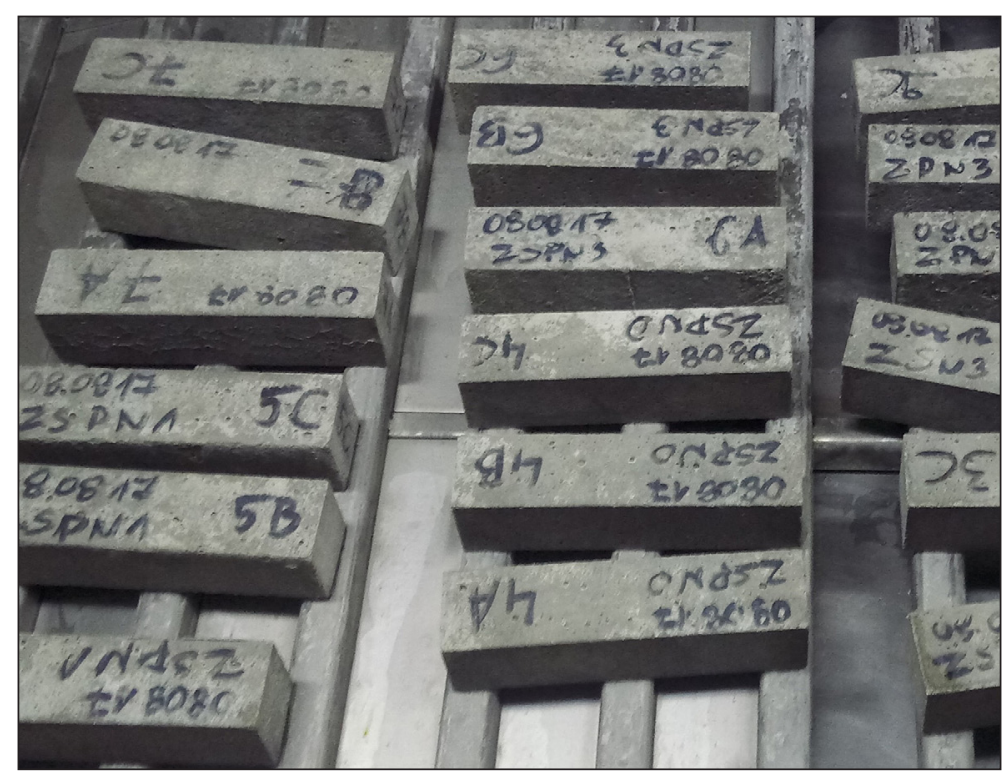

Figure 12. The samples after 25 freeze/thaw cycles 


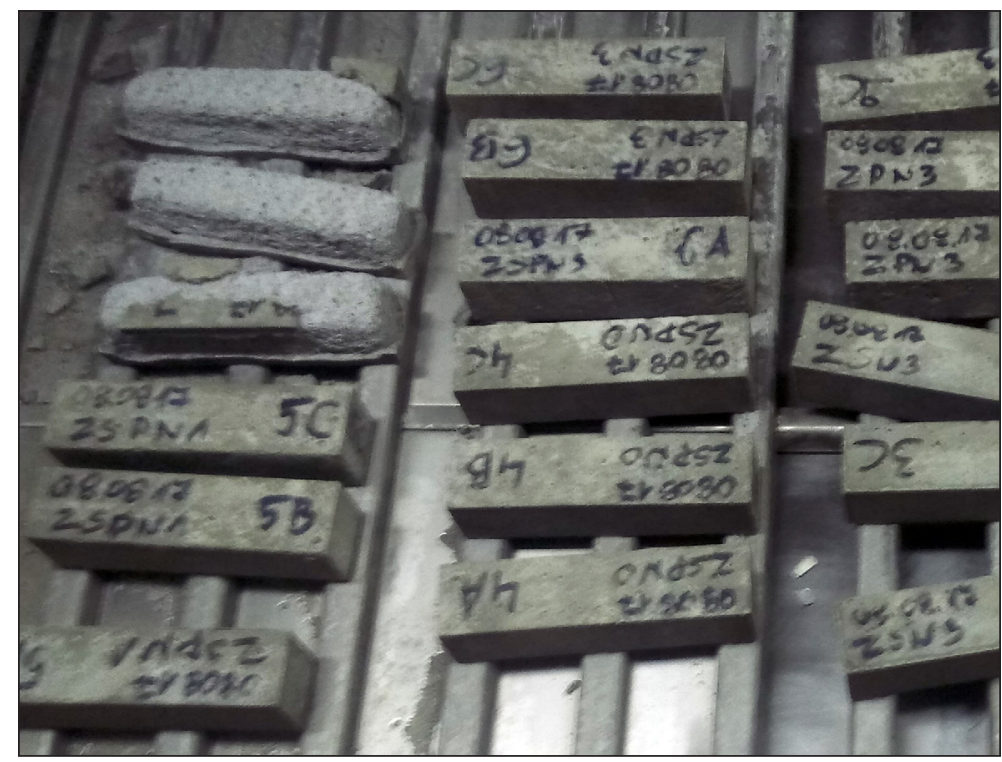

Figure 13. The samples after 100 freeze/thaw cycles. Clearly visible total destruction of the R0 samples

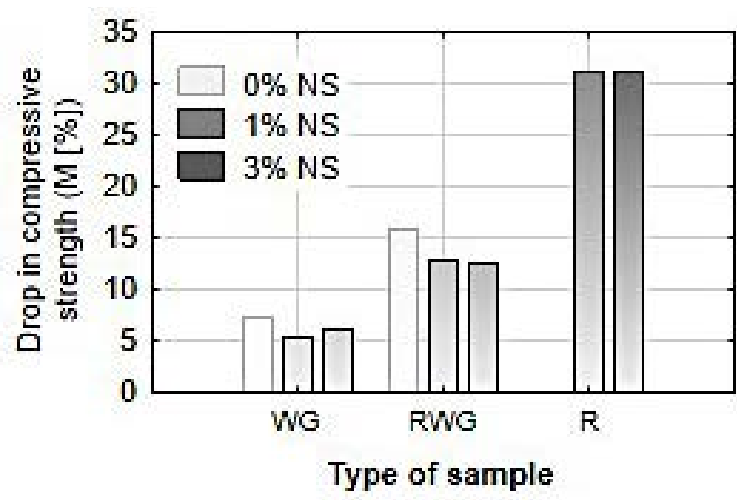

Figure 14. Drop in the compressive strength of mortars after freeze/thaw test

both aggregates have a similar Mosh hardness of 6-7. Natural sand is also one of the components of glass.

\section{CONCLUSIONS}

The performed laboratory tests on the influence of the waste glass grain shape and addition of the nanosilica on the properties of the cement mortars allowed drawing the following conclusions:
- Rough edges of waste glass grains affect the workability of the mix due to particle blocking. The mortars with glass cullet have lower bulk density and less plastic consistency. Total replacement of natural sand with waste glass, as well as the addition of the nanosilica increases the both compressive and flexural strength of mortars and their freeze/thaw resistance.

- The increase in strength of mortars produced with waste glass was attributed to internal blocking and increases friction. The size of the waste glass particles also influences the pozzolanic processes. The mortars with waste glass aggregate exhibit almost five times higher resistance to freeze/thaw than the mortars with natural sand.

- Evaluation of the fractured surfaces after the flexural strength tests allowed determining that in the samples with natural sand, the fracture propagates mostly through cement matrix. In the samples with waste glass the fracture progressed through bot matrix and glass grains.

- The addition of the nanosilica, due to infiltration of the pores, increases the abrasion resistance of cement mortars. The influence of aggregate type was not observed.

Table 4. Removed material volume per $5000 \mathrm{~mm}^{2}$

\begin{tabular}{|l|c|c|c|c|c|c|c|c|c|}
\hline $\begin{array}{l}\text { Sample } \\
\text { designation }\end{array}$ & WG0 & WG1 & WG3 & RWG0 & RWG1 & RWG3 & R0 & R1 & R3 \\
\hline$\left[\mathrm{mm}^{3} / 5000 \mathrm{~mm}^{2}\right]$ & 22500 & 20500 & 19000 & 21500 & 20000 & 18500 & 22000 & 20500 & 19500 \\
\hline
\end{tabular}




\section{REFERENCES}

1. Aly M., Hashmi M.S.J., Olabi A.G., Messeiry M., Abadir E.F., Hussain A.I. 2012. Effect of colloidal nano-silica on the mechanical and physical behavior of waste-glass cement mortar. Materials and Design, 33, 127-135.

2. Batayneh M., Marie I., Asi I. 2007. Use of selected waste materials in concrete mixes. Waste Management (New York, N.Y.), 27, 1870-1876.

3. Behfarnia K., Salemi N. 2013. The effects of nanosilica and nano-alumina on frost resistance of normal concrete. Construction and Building Materials, 48, 580-584.

4. Beigi M. H. et al. 2013. An experimental survey on combined effects of fi bers and nanosilica on the mechanical, rheological, and durability properties of self-compacting concrete. Materials and Design, 34, 1019-1029.

5. Carsana M., Frassoni M., Bertolini L. 2014. Comparison of ground waste glass with other supplementary cementitious materials. Cement \& Concrete Composites, 45, 39-45.

6. European Parliament. 2018. Directive (EU) 2018/852 of The European Parliament And Of The Council of 30 May 2018 amending Directive 94/62/ EC on packaging and packaging waste.

7. Du H., Tan K. H. 2014. Concrete with Recycled Glass as Fine Aggregates. ACI Materials Journal/ January-February, 47-57.

8. Givi A. N., Rashid S. A., Aziz F. N. A. et al. 2011. The effects of lime solution on the properties of $\mathrm{SiO} 2$ nanoparticles binary blended concrete. Composites: Part B, 42, 562-569.

9. Global Commission. 1987. Gathering a body of global agreements, Report of the World Commission on Environment and Development: Our Common.

10. Główny Urząd Statystyczny. 2018. Ochrona Środowiska 2018, Warszawa, ISSN 0867-3217, 140-157.

11. Gopalakrishnan R., Govindarajan D. 2011. Compressive Strength and Electron Paramagnetic Resonance Studies on Waste Glass Admixtured Cement. New Journal of Glass and Ceramics, 1(3), 119-124.

12. Gunalaan V., Kanapathy Pillary S. G. 2013. Performance of using waste glass powder in concrete as replacement of cement. American Journal of Engineering Research (AJER), 2, 175-181.

13. Horszczaruk E., Mijowska E., Cendrowski K., Sikora P. 2014. Influence of the new method of nanosilica addition on the mechanical properties of cement mortars. Cement Wapno Beton-5/2014, 66, 308-316.

14. Idir R., Cyr M., Tagnit-Hamou A. 2010. Use of fine glass as ASR inhibitor in glass aggregate mortars. Construction and Building Materials, 24, 1309-1312.

15. Ismail Z.Z., Al-Hashmi E.A. 2009. Recycling of waste glass as a partial replacement for fine aggregate in concrete, Waste Management (New York, N.Y.), 29, 655-659.

16. ISIC.1992. Określenie kryteriów zmniejszania zużycia ciepła w przemyśle szklarskim, Kraków.

17. Journal of the World Resource Foundation. 1996. Glass Re-use and recycling. Warner Bulletin, 49, Tonbridge.

18. Kuśnierz A. 2010. Recykling szkła. Prace Instytutu Ceramiki i Materiałów Budowlanych 2010, Tom: R. 3, nr 6, 22-33.

19. Ltifi M., Guefrech A., Mounanga P. et al. 2011. Experimental study of the effect of addition of nanosilica on the behaviour of cement mortars. Procedia Engineering, 10, 900-905.

20. Mageswari M., Vidivelli B. 2010. The use of sheet glass powder as fine aggregate replacement in concreto. Open Civil Engineering Journal, 4, 65-71.

21. Pawłowski W., Stoch L. 1995. Recykling szkła, Wydawnictwo Poznańskie, Poznań.

22. Park S.B., Lee B.C., Kim J. H. 2004. Studies on mechanical properties of concrete containing waste glass aggregate. Cement and concrete research, 34, 2181-2189.

23. Pereira de Oliveira L.A., Castro-Gomes J.P., Santos P. 2008. Mechanical and durability properties of concrete with ground waste glass sand. 11DBMC International Conference on Durability of Building Materials and Components, Istanbul, Turkey 11-14 May 2008, T11.

24. Polat R., Yadollahi M.M., Sagsoz A.E., Arasan S. 2013. The correlation between aggregate shape and compressive strength of concrete: Digital image processing approach. Int. J. Struct. Civ. Eng. Res., 2, 63-80.

25. Senff L. et al. 2012. Effect of nano-SiO2 and nano$\mathrm{TiO} 2$ addition on the rheological behavior and the hardened properties of cement mortars. Materials Science and Engineering A, 532, 354-361.

26. Shakhmenko G., Juhnevica I., Korjakins A. 2013. Influence of sol-gel nanosilica on hardening processes and physically-mechanical properties of cement paste. Procedia Engineering, 57, 1013-1021.

27. Sikora P., Abd Elrahman M., Stephan D. 2018. The influence of nanomaterials on the thermal resistance of cement-based composites-A review. Nanomaterials $8(7), 465$.

28. Sikora P., Augustyniak A., Cendrowski K., Horszczaruk E., Rucinska T., Nawrotek P., Mijowska E. 2016. Characterization of mechanical and bactericidal properties of cement mortars containing 
waste glass aggregate and nanomaterials. Materials 9 (8), no. 701, 1-16.

29. Skoczylas K., Rucińska T. 2018. Strength and durability of cement mortars containing nanosilica and waste glass fine aggregate. Cement Wapno Beton, 3/2018, 206-215.

30. Skoczylas K., Rucińska T. 2018. The effects of waste glass cullets and nanosilica on the long-term properties of cement mortars. E3S Web of Conferences 49, 00102, 1-9.
31. Sordoń-Kulibaba B. 2008. Zagospodarowanie odpadów szkła i opakowań szklanych. Recykling nr 3.

32. Terro M.J. 2006. Properties of concrete made with recycled crushed glass at elevated temperatures. Building and Environment, 41/2006, 633-639.

33. United Nations. 1992. AGENDA 21, United Nations Conference on Environment \& Development Rio de Janerio, Brazil, 3 to 14 June 1992.

34. Wiliams P.T. 1998. Waste treatment and disposal. John Wiley \& Sons Ltd, Chichester, UK. 